\title{
An Evaluation of the Factors Influencing Customers' Experience in Supermarkets of Bangladesh
}

\author{
Md. Nafizur Rahman ${ }^{1^{*}} \quad$ Nowshin Nower Rashik Hassan Zeba Samiha \\ Department of Finance \& Banking, Bangladesh University of Professionals, Mirpur Cantonment, 1216, Dhaka, \\ Bangladesh
}

\begin{abstract}
The supermarket industry of Bangladesh came off the ground in the early 2000s. The industry has witnessed steady growth over this time-frame. Mostly run by three key players Shwapno, Agora and Meena Bazar, the industry has brought to a certain extent a major shift of consumer shopping preferences from mom-and-pop stores to the superstores. The rise of the middle class and its growing buying power drive the growth of Bangladesh's supermarket business. The sector is likely to witness further growth due to rapid urbanization and higher per capita income, according to market players. The market size of the country's supermarket is approximately Tk. 2,500 crore, and the growth has been nearly 15 percent per year over the past couple of years. Faced with many obstacles such as the imposition of VAT, scarcity of proper commercial space and a yet-to-be-robust value chain, the industry is making progress towards growth. The top players jumped on the bandwagon to create a superior "Supermarket Experience" for their valued customers. This study aims at investigating the factors that affect customers' experience in supermarkets of Bangladesh. Secondary data were used to review the literature and primary data were used to conduct the analysis. A sample of 206 customers who regularly visit supermarkets were interviewed using a structured questionnaire. Both descriptive and inferential analysis were used to analyze the data. Multivariate analysis such as- Exploratory factor analysis was used to identify the factors that significantly influence customers' experience in supermarkets. Multiple regression analysis was performed to identify the relationship between the factors and the overall customers' experience in supermarkets of Bangladesh. The result shows that factors such as, time saving, staff assistance and responsiveness, product authenticity with clear labeling, return policy, flexible mode of payment, convenient location and competitive pricing are the important factors that influence customers' experience in supermarkets of Bangladesh. This study suggests that the super chain owners should focus more on saving customers' time, staff assistance and responsiveness, ensuring authenticity of goods by clearly labeling, liberal return policy, flexible mode of payment such as- card and digital payment, convenient store location and competitive pricing of goods compared to the local wet markets to improve the customers' experience in supermarkets of Bangladesh.
\end{abstract}

Keywords: Customers' experience, Time saving, Staff assistance, Product authenticity, Flexible mode of payment, Competitive pricing.

DOI: $10.7176 / \mathrm{EJBM} / 11-26-02$

Publication date:September $30^{\text {th }} 2019$

\section{Background}

The Global Supermarket Industry is a century long one and supermarkets have been dominating food sales in developed countries since its inception. Supermarkets are no longer popular in only urban areas, but have now evolved and spread to semi-urban and even urban-slum areas from providing domestic items to canned and processed food to local produces. A "supermarket revolution" began in the developing countries in the early 1990s and this diffusion of modern food retail rolled out in three waves. Thomas Reardon, a professor at the Department of Agricultural, Food and Resource Economics at Michigan State University, stated that Bangladesh is actually a part of a fourth wave that just barely has emerged in the last few years (IDLC Monthly, Volume 13). The country only became a part of the supermarket industry in the early 2000 s.

The retailing sector in Bangladesh is underdeveloped and fragmented compared to its South Asian counterparts and neighboring countries. The retail industry in India is the fifth largest in the world and is the second largest employer in the country, contributing to over 30\% to the GDP. However, according to the business director of "Shwapno"-the current market leader of the industry- the growth of retailing in Bangladesh is around $15 \%$. Consumers from the middle and affluent classes prefer buying everything under one roof to save time and energy and coming to a supermarket where a wide array of products are available does exactly that. Bangladesh only introduced retailed services with "Agora" in 2001 and since then, the industry has managed to attract many investors. Currently there 121 supermarkets in the country and the industry leader, Shwapno, has the highest number of 76 outlets in the major cities such as Dhaka, Chattogram, Cumilla, Gazipur and Sylhet. The market size of BDT 1500 crores in 2015 has been expected to grow by 15 times by 2021 .

Bangladesh is one of the fastest growing economies in the world reaching an all-time high GDP Annual Growth Rate of 7.11 in 2019. According to the Daily Star- one of Bangladesh's leading newspapers- the rise of the middleclass and their growing purchasing power are the driving forces of the growth of the supermarket 
industry in Bangladesh. And according to a research conducted by IDLC Finance Limited, the industry-mostly run by three key players- has witnessed a gradual shift in consumer shopping preference to supermarkets from the mom-and-pop shops or wet markets. Supermarkets in Bangladesh have already started infusing e-commerce into their business to ensure that customers do not face any shopping difficulties. In a city like Dhaka, where the average traffic speed is only $7 \mathrm{~km} /$ hour, this service is befitting. However, as the industry is in its early stages, it only scratches the surface of the potential advantages that comes with online and offline shopping experiences. Super shops find it difficult to attract consumers with VAT implemented on their products as the wet market does not charge any VAT. But the health-conscious consumers are giving supermarkets scopes to promote safer and more organic food in a cleaner environment. Technological development and implementation into this industry is at a rise along with promotional activities as more players venture into this industry.

\begin{tabular}{|l|c|c|}
\hline \multicolumn{3}{|c|}{ Table 1: Overview of the Supermarket Sector of Bangladesh } \\
\hline Supermarket Brand & Number of Outlets & Market Share \\
\hline 1. Shawpno & 59 & $30 \%$ \\
\hline 2. Agora & 13 & $22 \%$ \\
\hline 3. Meena Bazar & 18 & $18 \%$ \\
\hline 4. Others & 31 & $30 \%$ \\
\hline Total & 121 & $100 \%$ \\
\hline
\end{tabular}

Source: LightCastle Primary Research, 2014

Right now, there are about 40 supermarket chains operating in Bangladesh with more than 130 outlets according to Bangladesh Supermarket Owners' Association (BSOA). A great number of customers visit these supermarkets every day. Hence, this study has been conducted to identify the factors responsible for of the customers' experience in the supermarkets of Bangladesh.

\section{Objectives of the Study}

The broad objective of this study is to identify the factors influencing customers' experience in supermarkets of Bangladesh. The specific objectives are as follows.

i. To describe the customers' experience of supermarkets in Bangladesh;

ii. To identify the factors that influence customers' experience in super shops of Bangladesh;

iii. To identify the significant factors related to the customers' experience in supermarkets of Bangladesh;

\section{Literature Review}

Supermarket, a form of self-serviced grocery store, has undergone significant expansion and growth in recent years in Bangladesh. In the midst of serious competition and increasing number of supermarket outlets offering a wide range of products, customers have become acquainted with patronizing various outlets. Antecedents such as perceived service quality, trust, perceived price and perceived product variety have significant impact on the customers' satisfaction in super shops of Bangladesh. (Chowdhury et al., 2014). Customers' experience and satisfaction varies person to person as no two human beings have indistinguishable perception. The measurement of contentment on supermarkets of Bangladesh depends on the different components such as age, gender, education level, income and expenditure, monthly visit frequency to supermarket, product assortment and price of the products, quality, convenience, hygiene and environment. (Azad, S. N., Hossain, M. M., \& Parveen, R., 2011).

A supermarket's performance mostly relies on the level of satisfaction of its customers. Any issue with the customer service creates the discontent of the customer. An effective measuring and tracking system is crucial for ensuring appropriate customer management and quality service in supermarkets of Bangladesh. Six significant factors affect a customer's purchasing experience in Bangladesh supermarkets. The factors include availability, quality, convenience, cost, location, and atmosphere of the supermarket outlets. (Hossain, M., Rahman, D., \& Akter, N., 2009). Another study found that price is the most important factor affecting customers' experience in supermarkets followed by responsiveness and product quality. (Rana, S. S., Osman, A., \& Islam, M. A., 2014).

The Bangladeshi supermarket industry has taken a steady growth in the nation since the start of Agora's journey in 2001. The domestic supermarket industry now stands at about BDT 1,500 crore. Because of Bangladeshi people's shifting income to middle-income status, all subsequent benefits, including per capita raising and urbanization, are accelerating the profitability and development of this industry. Bangladesh's supermarket industry is expected to grow by nearly 15 times its current size by 2021 with rapid urbanization. Therefore, customer satisfaction became an important concern for entrepreneurs in this sector due to the increasing demand of supermarkets. Factors affecting supermarket customer satisfaction in Bangladesh are concerned with seller's personal interaction, marketer's problem-solving attitude, and supermarket authority's service policy. (Islam, D., 2018). (Thurong, 2016) found that product, price, personal interaction, convenience, services and physical appearance implies positive customer experience towards supermarkets.

(Huddleson, 2009) has compared perception related to customers' satisfaction with conventional stores in comparison with specialty stores. The study reveals that product assortment, price, quality and service are the 
major factors determining the dissimilarity in satisfaction between shopping from a conventional store to shopping from a super shop. Price plays the most vital role in terms of maintaining relation with customers because it is an important component of the perception of value, which has an effect on positive experience of customers. (Varki, S., \& Colgate, M., 2001).

According to (Fitzsimmons et al., 2004) personal interaction with customers can enhance the shopping experience or else causes dissatisfaction. The effect of dissatisfaction on new customers and existing customers was studied by many researchers. The study says that dissatisfaction has more negative effect on a new customer than on remaining customers. Findings of the study stated that customer familiarity causes greater satisfaction and results loyalty. (Bloemer, J., \& De Ruyter, K., 1998). Globally, the creation of a superior customer experience has gained more attention from retailers. Study (Shamsudeen, S., 2017) has attempted to provide a full image of customer experience and its determinants among clients in supermarkets. Customers' experience in supermarkets are mostly affected by determinants namely social environment, store atmosphere, price and past experience. Understanding the client and the main determinants of his experience are critical for the retailer to resist the market's competition. Past experience, store atmosphere, cost, social environment and alternative channel experience play a significant part in generating a superior customer experience in the case of supermarket experience. (Ramya, D., 2015).

According to (Mohan, R., 2013) customer service, store environment, brand variety, location and shopping convenience has greater impact on customers' satisfaction in food retail supermarkets. Friendliness and caring treatment are valued by customers and a supermarket needs to provide these in order to succeed in the market full of competition. Study says customer service should be considered to be an important factor to gain customer loyalty and future patronage. (Abubakar, B., Mavondo, F., \& Clulow, V., 2001). Factors such as responsiveness and convenience also affect customers experience. (Islam et al., 2019). Retailers need to be quite proactive in conducting customer surveys from time to time to assess their customer services. This will allow them to attain customer satisfaction, customer loyalty and customers' patronage towards the store. Supermarkets' survival and profitability, like any other business, rely on customer patronage. (Karumba, T., \& Ngigi, P., 2018). Hence, supermarket experience is concerned with some important factors. The important issues related to supermarket concerning the customers experience are shown in Table 2.

Table 2 Literature Review on Customers' Experience in Supermarkets of Bangladesh

\begin{tabular}{|c|c|c|c|c|c|c|c|c|c|c|c|c|c|c|c|}
\hline Authors & Price & \begin{tabular}{|l|l|} 
Loyalty \\
\end{tabular} & $\begin{array}{l}\text { Brand } \\
\text { Image }\end{array}$ & Convenience & \begin{tabular}{|l|} 
Assortment \\
\end{tabular} & Service & Quality & Trust & $\begin{array}{l}\text { Cleanliness } \\
\text { and hygiene }\end{array}$ & $\begin{array}{l}\text { CardSmart } \\
\text { payment } \\
\text { facility }\end{array}$ & Location & $\begin{array}{l}\text { Parking } \\
\text { Facility }\end{array}$ & Enviromment & $\begin{array}{l}\text { Promotional } \\
\text { Offers }\end{array}$ & $\begin{array}{l}\text { Operating } \\
\text { hour }\end{array}$ \\
\hline $\begin{array}{l}\text { (Hossain, M., Rahman, } \\
\text { D., \& \& Akter, N, 2009). }\end{array}$ & v & & & v & & v & $\checkmark$ & & & & v & & v & & \\
\hline $\begin{array}{l}\text { (Azad, S. N., Hossain, M. } \\
\text { M., \& Parveen,R, 2011) }\end{array}$ & $\checkmark$ & & & v & v & v & v & & a & $\mathrm{d}$ & v & & 4 & & \\
\hline (Islam, D., 2018). & & v & & & v & & & & & & & & & & \\
\hline (Shamsuden, S., 2017 & v & & & & v & 4 & & & & & & & v & & \\
\hline Ramya, D. (2015). & $\checkmark$ & & & & $\checkmark$ & $\checkmark$ & & & & & & & v & & \\
\hline $\begin{array}{l}\text { (Karumba, T., \& Ngigi, } \\
\text { P., 2018) }\end{array}$ & & & & & & v & & & & $\checkmark$ & & & v & v & $\checkmark$ \\
\hline $\begin{array}{l}\text { (Pilelené, L., \& } \\
\text { Grigaliunaite, }, \mathrm{V}, 2013)\end{array}$ & & v & v & & & & v & & & & & & & & \\
\hline $\begin{array}{l}\text { (Choordhury et al, } \\
\text { 2014). }\end{array}$ & $\checkmark$ & v & & & $\checkmark$ & v & & $\checkmark$ & & & & & & & \\
\hline $\begin{array}{l}\text { (Rana, S. S., Osman, A., } \\
\text { \& Islam, M.A., 2014) }\end{array}$ & $\checkmark$ & & & & & & $\checkmark$ & & & & & & & & \\
\hline (Rasoly, M, 2018) & $\checkmark$ & & & v & & & & & & $\checkmark$ & & & v & & \\
\hline $\begin{array}{l}\text { (Abubakar, B, Marondo, } \\
\text { F, \& Clulow, V, 2001). }\end{array}$ & 1 & & $\checkmark$ & & 4 & & $\checkmark$ & & 4 & & & v & & & \\
\hline $\begin{array}{l}\text { (Bloemer, J., \& De } \\
\text { Ruyter, K, 1998) }\end{array}$ & & v & v & & & & & & & & & & & & \\
\hline (Throng, 2016) & $\checkmark$ & & & $\checkmark$ & v & v & $\checkmark$ & & & & & & & & \\
\hline Mohan, R. (2013). & v & & & $\checkmark$ & v & v & v & & v & v & & & & & $\checkmark$ \\
\hline
\end{tabular}

\section{Methodology}

This purpose of this study was to identify the factors concerning the customers' experience in supermarkets of Bangladesh. The research was conducted using both primary and secondary data. Primary data were collected from the customers who visit supermarkets regularly and the secondary data were collected from the books, magazines, and journals. 
4.1 Demographic Information of the Respondents

This study conducted study on 207 supermarket customers in Bangladesh. Among the respondents, 51.70\% of the respondents were male and $48.30 \%$ were female (Table 3 ).

Table 3 Gender Distribution of the Respondents

\begin{tabular}{|l|l|l|l|l|}
\hline Gender & Frequency & Percent & Valid Percent & Cumulative Percent \\
\hline Male & 107 & 51.7 & 51.7 & 51.7 \\
\hline Female & 100 & 48.3 & 48.3 & 100.0 \\
\hline Total & 207 & 100.0 & 100.0 & \\
\hline
\end{tabular}

The respondent supermarket customers mostly (30.0\%) were at the age of 30-35 years followed by 36-41 years $(20.3 \%)$, above 41 years $(17.9 \%), 18-23$ years $(16.9 \%)$, and $24-29$ years $(15 \%)$ (Table 4$)$.

Table 4 Age of the Respondents

\begin{tabular}{|c|c|c|c|c|}
\hline Age in Years & Frequency & Percent & Valid Percent & Cumulative Percent \\
\hline 18 to 23 & 35 & 16.9 & 16.9 & 16.9 \\
\hline 24 to 29 & 31 & 15.0 & 15.0 & 31.9 \\
\hline 30 to 35 & 62 & 30.0 & 30.0 & 61.8 \\
\hline 36 to 41 & 42 & 20.3 & 20.3 & 82.1 \\
\hline Above 41 & 37 & 17.9 & 17.9 & 100.0 \\
\hline Total & 207 & 100.0 & 100.0 & \\
\hline
\end{tabular}

Table 5 shows that 25.1 percent of the respondents were unmarried and 74.9 percent respondents were married.

Table 5 Marital Status of the Respondents

\begin{tabular}{|l|l|l|l|l|}
\hline Marital Status & Frequency & Percent & Valid Percent & Cumulative Percent \\
\hline Single & 52 & 25.1 & 25.1 & 25.1 \\
\hline Married & 155 & 74.9 & 74.9 & 100.0 \\
\hline Total & 207 & 100.0 & 100.0 & \\
\hline
\end{tabular}

Table 6 shows that the respondent's highest level of education was bachelor degree (43.0\%) followed by master degree $(42.5 \%)$, higher secondary $(13.0 \%)$ and secondary level $(1.4 \%)$.

Table 6 Distribution of Education of Respondents

\begin{tabular}{|l|l|l|l|l|}
\hline Highest Level of Education & Frequency & Percent & Valid Percent & Cumulative Percent \\
\hline Secondary & 3 & 1.4 & 1.4 & 1.4 \\
\hline Higher secondary & 27 & 13.0 & 13.0 & 14.5 \\
\hline Bachelor degree & 89 & 43.0 & 43.0 & 57.5 \\
\hline Master degree or above & 88 & 42.5 & 42.5 & 100.0 \\
\hline Total & 207 & 100.0 & 100.0 & \\
\hline
\end{tabular}

Most of the customers under study visit supermarkets monthly followed by weekly, more than once in a month, and daily. (Table 7).

Table 7 Frequency of visit of the Respondents

\begin{tabular}{|c|c|c|c|c|}
\hline Frequency of Visiting Supermarket & Frequency & Percent & Valid Percent & Cumulative Percent \\
\hline Daily & 9 & 4.3 & 4.3 & 4.3 \\
\hline Weekly & 73 & 35.3 & 35.3 & 39.6 \\
\hline Monthly & 78 & 37.7 & 37.7 & 77.3 \\
\hline More than once in a month & 47 & 22.7 & 22.7 & 100.0 \\
\hline Total & 206 & 100.0 & 100.0 & \\
\hline
\end{tabular}

4.2 Sample Design and Determination of Sample Size

There are around 130 supermarket outlets in Bangladesh. According to the owner of the leading supermarket chain Meena Bazar, more than 10000 customers visit a Meena Bazar outlet every day to buy their necessary stuffs. ${ }^{1}$ The

\footnotetext{
${ }^{1}$ Supermarkets: New Trend in Urban Shopping Reshaping Modern Retail Trade. (2017). IDLC Monthly Business Review,13(10). Retrieved
} 
sample size of this study was therefore determined using Yamane's (1967) suggested formula below.

$$
n=\frac{N}{1+N(e)^{2}}
$$

Where $\mathrm{n}$ is the sample size, $\mathrm{N}$ is the size of the population, and $\mathrm{e}$ is the precision level. The level of precision is presumed to be 0.07 for this study and the population size is 1300000 . By placing these values in the above equation, the required number of sample size turns out to be around 204. This study interviewed 207 customers who frequently visit supermarkets in Bangladesh. For multivariate analysis, this figure is well above the critical sample size of 204 (Hair et al., 1998).

Taking into account the customers' accessibility and willingness to respond to this study, Convenience Sampling Method was used to select the sampling units (Malhotra, 2007).

\subsection{Questionnaire Design}

In this study, the structured questionnaire developed by Dabholkar (1996) was used to gather information from customers of supermarkets. Responses to all of the questionnaire statements were measured on a five-point scale ranging from 1 to 5 with 1 indicating strongly disagree and 5 indicating strongly agree with the statement. One of the relative advantages of using this scale is its suitability to apply multiple statistical tools used in the study of marketing and social research (Malhotra, 1999). Subsequently, the data collected were processed statistically to obtain the useful information. The statistics on reliability demonstrates that the questionnaire's internal consistency is under the acceptable limit (Nunnally, 1978). The alpha coefficient for the 24 items is 0.854 which suggests that the items of the questionnaires have relatively high internal consistency. Thus, the reliability statistics of the data set are at acceptable level (Table 8).

Table 8 Reliability Statistics of the Data Set

\begin{tabular}{|c|c|}
\hline Cronbach's Alpha & N of Items \\
\hline 0.854 & 24 \\
\hline
\end{tabular}

\subsection{Data Collection}

Data were collected from both primary and secondary sources to conduct this study. Primary data were used for the purpose of identifying the factors influencing customers' experience in supermarkets of Bangladesh. The survey was conducted among the customers of four supermarket chains of Bangladesh. The survey was conducted in 2019. The interviewers were properly trained on the items included in the questionnaire for data collection before commencing the interview.

4.5 Normality of Data

According to Tabachnick and Fidell (2001), the value of the statistics for Skewness and Kurtosis ranges from-4 to +4 , which is considered acceptable. Table 9 shows that all data were within the acceptable range indicating normal data distribution. 
Table 9 Normality of the Information

\begin{tabular}{|c|c|c|c|}
\hline \multicolumn{4}{|l|}{ Descriptive Statistics } \\
\hline \multirow{2}{*}{ Variables } & $\mathrm{N}$ & Skewness & Kurtosis \\
\hline & Statistic & Statistic & Statistic \\
\hline 1. Supermarkets of Bangladesh ensure hygiene & 207 & -.703 & .905 \\
\hline 2. Supermarkets are cleaner than local wet markets & 207 & -1.395 & 4.654 \\
\hline 3. A wide range of goods are available in supermarkets & 207 & -.950 & 1.776 \\
\hline 4. I find high quality products in supermarkets & 207 & -.358 & .256 \\
\hline 5. Original products with clear labels are available & 207 & -.494 & -.320 \\
\hline 6. Price of goods is appropriate to their quality & 207 & -.294 & -.669 \\
\hline 7. Supermarkets offer discounts on various occasions to the potential buyers & 207 & -.528 & -.344 \\
\hline 8. Price of goods in supermarkets is competitive & 207 & -.233 & -.999 \\
\hline 9. Supermarkets provide membership cards to the regular customers & 207 & -1.139 & 3.699 \\
\hline 10. The staffs of the supermarkets are polite and supportive & 207 & -.883 & 2.449 \\
\hline 11. I get proper staff assistance during my shopping & 207 & -.749 & .576 \\
\hline 12. Staffs are highly responsive in supermarkets & 207 & -.396 & -.190 \\
\hline 13. Supermarket always ensures correct billing. & 207 & -1.072 & 2.246 \\
\hline 14. Shopping in supermarket saves time & 207 & -.960 & 1.514 \\
\hline 15. Store atmosphere is satisfactory & 207 & -1.232 & 3.747 \\
\hline 16. Supermarkets in Bangladesh provides parking facilities & 207 & -.115 & -.958 \\
\hline 17. Supermarkets have good return policies & 207 & .040 & -.570 \\
\hline 18. Mode of payment is flexible (Card/Digital payment) & 207 & -.238 & -.158 \\
\hline 19. Supermarkets provide regular feedback to customer complaints & 207 & -.259 & -.083 \\
\hline 20. I feel safer while shopping in supermarkets than in local retail stores. & 207 & -.586 & .443 \\
\hline 21. The number of supermarkets in my area is satisfactory & 207 & -.705 & -.176 \\
\hline 22. Store location is convenient to me & 207 & -.640 & .361 \\
\hline 23. The operating time of supermarkets is convenient & 207 & -.223 & -.072 \\
\hline $\begin{array}{l}\text { 24. Considering all the factors mentioned above, I think I am satisfied with } \\
\text { the supermarkets of Bangladesh. }\end{array}$ & 207 & -.943 & 1.176 \\
\hline
\end{tabular}

4.6 Analytical Tools

The data was analyzed using both descriptive and inferential statistics. Descriptive statistics ${ }^{1}$, such as mean, standard deviation, a simple percentage was used to describe Bangladesh's supermarket experience for customers. In addition to descriptive statistics, inferential statistical ${ }^{2}$ techniques like Factor Analysis and Multiple Regression Analysis have been used to analyze data. A Principal Component Analysis (PCA) with an Orthogonal Rotation (Varimax) $)^{3}$ using the SPSS (Statistical Package for Social Sciences) version 20.0 was performed on the collected data. To identify the relationships between the model's dependent and independent variables, multiple regression analysis was conducted. Inferential statistics such as Exploratory Factor Analysis (EFA) were used to separate factors in the supermarket experience of the customers. Multiple Regression Analysis ${ }^{4}$ (MRA) was used to identify

\footnotetext{
${ }^{1}$ Descriptive statistics includes statistical procedures that we use to describe the population we are studying. The data could be collected from either a sample or a population, but the results help us organize and describe data. Descriptive statistics can only be used to describe the group that is being studying. That is, the results cannot be generalized to any larger group.

${ }^{2}$ Inferential statistics is concerned with making predictions or inferences about a population from observations and analyses of a sample. That is, we can take the results of an analysis using a sample and can generalize it to the larger population that the sample represents.

${ }^{3}$ Varimax rotation is an orthogonal rotation of the factor axes to maximize the variance of the squared loadings of a factor (column) on all the variables (rows) in a factor matrix, which has the effect of differentiating the original variables by extracted factor. Each factor will tend to have either large or small loadings of any particular variable. A varimax solution yields results which make it as easy as possible to identify each variable with a single factor. This is the most common rotation option.

${ }^{4}$ In statistics, regression analysis is a statistical process for estimating the relationships among variables. It includes many techniques for modeling and analyzing several variables, when the focus is on the relationship between a dependent variable and one or more independent variables. More specifically, regression analysis helps one understand how the typical value of the dependent variable (or 'Criterion Variable') changes when any one of the independent variables is varied, while the other independent variables are held fixed.
} 
the significant factors from the factors identified by factor analysis.

\section{Analysis and Interpretations}

In the analysis part of this paper, multivariate analysis like factor analysis and multiple regression analysis were performed.

5.1 Results of Exploratory Factor Analysis (EFA)

According to Hair et al. (2010), if Kaiser-Meyer-Olkin (KMO) test and Bartlett's sphericity test are significant, the factor analysis can be performed. An index of Kaiser-Meyer-Olkin's sampling adequacy measures (Overall MSA= $0.797)$ and Bartlett's Sphericity Test $\chi 2(p=0.000)$ suggested that the factor analysis would be appropriate for the data analysis (Table 10).

Table $10 \mathrm{KMO}$ and Bartlett's Test

\begin{tabular}{|l|c|c|}
\hline \multicolumn{2}{|c|}{ Kaiser-Meyer-Olkin Measure of Sampling Adequacy. } & .797 \\
\hline \multirow{3}{*}{ Bartlett's Test of Sphericity } & Approx. Chi-Square & 1313.652 \\
\cline { 2 - 3 } & $\mathrm{df}$ & 253 \\
\cline { 2 - 3 } & Sig. & .000 \\
\hline
\end{tabular}

The results of factor analysis show that all the variable concerning the customers' experience in supermarkets of Bangladesh have high communalities indicating the variables are important in this study. It demonstrates that the extracted components represent the variables well. (Table 11).

\begin{tabular}{|l|c|}
\hline \multicolumn{1}{|c|}{ Table 11 Communalities of the Variables } & Extraction \\
\hline \multicolumn{1}{|c|}{ Variables } & .544 \\
\hline 1. Supermarkets of Bangladesh ensure hygiene & .539 \\
\hline 2. Supermarkets are cleaner than local wet markets & .536 \\
\hline 3. A wide range of goods are available in supermarkets & .545 \\
\hline 4. I find high quality products in supermarkets & .656 \\
\hline 5. Original products with clear labels are available & .602 \\
\hline 6. Price of goods is appropriate to their quality & .574 \\
\hline 7. Supermarkets offer discounts on various occasions to the potential buyers & .586 \\
\hline 8. Price of goods in supermarkets is competitive & .460 \\
\hline 9. Supermarkets provide membership cards to the regular customers & .750 \\
\hline 10. The staffs of the supermarkets are polite and supportive & .766 \\
\hline 11. I get proper staff assistance during my shopping & .697 \\
\hline 12. Staffs are highly responsive in supermarkets & .568 \\
\hline 13. Supermarket always ensures correct billing. & .541 \\
\hline 14. Shopping in supermarket saves time & .620 \\
\hline 15. Store atmosphere is satisfactory & .547 \\
\hline 16. Supermarkets in Bangladesh provides parking facilities & .663 \\
\hline 17. Supermarkets have good return policies & .648 \\
\hline 18. Mode of payment is flexible (Card/Digital payment) & .518 \\
\hline 19. Supermarkets provide regular feedback to customer complaints & .660 \\
\hline 20. I feel safer while shopping in supermarkets than in local retail stores. & .724 \\
\hline 21. The number of supermarkets in my area is satisfactory & .712 \\
\hline 22. Store location is convenient to me & .549 \\
\hline 23. The operating time of supermarkets is convenient & \\
\hline Extraction Method: Principal Component Analysis. & \\
\hline
\end{tabular}

The study identified seven factors related to the customers' experience in supermarkets of Bangladesh. It shows that time saving, staff assistance and responsiveness, product authenticity with clear labeling, return policy, flexible mode of payment, convenient store location and competitive pricing are important factors that influence the customers' experience in supermarkets of Bangladesh. The variance of factor named time-saving is the highest $(23.295 \%)$ followed by staff assistance and responsiveness $(8.743 \%)$, product authenticity with clear labeling (7.206\%), return policy $(6.606 \%)$, flexible mode of payment $(5.817)$, convenient store location $(4.784 \%)$, and competitive price of goods $(4.418 \%)$. The total variance of the data set is $60.868 \%$ indicates that major portion of the data set is included in the analysis. (Table 12).

The rotated factor analysis shows that the factors constituted with the variables have higher level of correlations between them. (Table 13). The first factor named time-saving is constituted with five variables followed by staff assistance and responsiveness with three variables, product authenticity with clear labeling with four variables, return policy with three variables, flexible mode of payment with four variables, convenient store 
location with two variables and competitive price with two variables.

Table 12 Factors and Total Variance Explained

\begin{tabular}{|c|c|c|c|}
\hline \multirow{2}{*}{ Factors } & \multicolumn{3}{c|}{ Initial Eigenvalues } \\
\cline { 2 - 4 } & Total & \% of Variance & Cumulative \% \\
\hline 1. Time Saving & 5.358 & 23.295 & 23.295 \\
\hline 2. Staff Assistance and Responsiveness & 2.011 & 8.743 & 32.038 \\
\hline 3. Product Authenticity with Clear Labeling & 1.657 & 7.206 & 39.243 \\
\hline 4. Return Policy & 1.519 & 6.606 & 45.850 \\
\hline 5. Flexible Mode of Payment & 1.228 & 5.817 & 51.667 \\
\hline 6. Convenient Location & 1.100 & 4.784 & 56.451 \\
\hline 7. Competitive Pricing & 1.016 & 4.418 & 60.868 \\
\hline
\end{tabular}

Extraction Method: Principal Component Analysis.

Table 13 Rotated Component Matrix

\begin{tabular}{|c|c|c|c|c|c|c|c|}
\hline & \multicolumn{7}{|c|}{ Component } \\
\hline Variables & 1 & 2 & 3 & 4 & 5 & 6 & 7 \\
\hline \multicolumn{8}{|c|}{ Factor 1 Time Saving } \\
\hline 1. Supermarkets of Bangladesh ensure hygiene & .518 & & & & & & \\
\hline 2. Supermarkets are cleaner than local wet markets & .674 & & & & & & \\
\hline 14. Shopping in supermarket saves time & .686 & & & & & & \\
\hline $\begin{array}{l}20 \text {. I feel safer while shopping in supermarkets than in local } \\
\text { retail stores. }\end{array}$ & .586 & & & & & & \\
\hline 23. The operating time of supermarkets is convenient & .463 & & & & & & \\
\hline \multicolumn{8}{|c|}{ Factor 2 Staff Assistance and Responsiveness } \\
\hline 10. The staffs of the supermarkets are polite and supportive & & .782 & & & & & \\
\hline 11. I get proper staff assistance during my shopping & & .827 & & & & & \\
\hline 12. Staffs are highly responsive in supermarkets & & .705 & & & & & \\
\hline \multicolumn{8}{|c|}{ Factor 3 Product Authenticity with Clear Labeling } \\
\hline 3. A wide range of goods are available in supermarkets & & & .503 & & & & \\
\hline 4. I find high quality products in supermarkets & & & .589 & & & & \\
\hline 5. Original products with clear labels are available & & & .692 & & & & \\
\hline 6. Price of goods is appropriate to their quality & & & 676 & & & & \\
\hline \multicolumn{8}{|c|}{ Factor 4 Return Policy } \\
\hline 16. Supermarkets in Bangladesh provides parking facilities & & & & .641 & & & \\
\hline 17. Supermarkets have good return policies & & & & .766 & & & \\
\hline $\begin{array}{l}\text { 19. Supermarkets provide regular feedback to customer } \\
\text { complaints }\end{array}$ & & & & .603 & & & \\
\hline \multicolumn{8}{|c|}{ Factor 5 Flexible Mode of Payment } \\
\hline $\begin{array}{l}\text { 7. Supermarkets offer discounts on various occasions to the } \\
\text { potential buyers }\end{array}$ & & & & & .500 & & \\
\hline 13. Supermarket always ensures correct billing. & & & & & .645 & & \\
\hline 15. Store atmosphere is satisfactory & & & & & .537 & & \\
\hline 18. Mode of payment is flexible (Card/Digital payment) & & & & & .660 & & \\
\hline \multicolumn{8}{|c|}{ Factor 6 Convenient Location } \\
\hline 21. The number of supermarkets in my area is satisfactory & & & & & & .819 & \\
\hline 22. Store location is convenient to me & & & & & & .821 & \\
\hline \multicolumn{8}{|c|}{ Factor 7 Competitive Pricing } \\
\hline 8. Price of goods in supermarkets is competitive & & & & & & & .752 \\
\hline $\begin{array}{l}\text { 9. Supermarkets provide membership cards to the regular } \\
\text { customers }\end{array}$ & & & & & & & .509 \\
\hline
\end{tabular}

Extraction Method: Principal Component Analysis.

Rotation Method: Varimax with Kaiser Normalization.

a. Rotation converged in 12 iterations. 
5.2 Results of Multiple Regression Analysis

Multiple regression result shows that the correlation is 0.702 and the adjusted $\mathrm{R}$ square is 0.475 which indicates higher level of relationship of the factors with the overall customers' experience in supermarkets of Bangladesh. (Table 14)

Table 14 Model Summary

\begin{tabular}{|c|c|c|c|c|}
\hline Model & $\mathrm{R}$ & R Square & Adjusted R Square & $\begin{array}{c}\text { Std. Error of the } \\
\text { Estimate }\end{array}$ \\
\hline 1 & $.702^{\mathrm{a}}$ & .493 & .475 & .56595 \\
\hline
\end{tabular}

a. Predictors: (Constant), REGR factor score 7 for analysis 1, REGR factor score 6 for analysis 1, REGR factor score 5 for analysis 1, REGR factor score 4 for analysis 1, REGR factor score 3 for analysis 1 , REGR factor score 2 for analysis 1 , REGR factor score 1 for analysis 1

Analysis of variance (ANOVA) shows that all the seven factors are significantly influence overall customers' experience in supermarkets of Bangladesh (Table 15).

Table 15 ANOVA $^{\mathrm{a}}$

\begin{tabular}{|l|l|l|l|l|l|l|}
\hline \multicolumn{2}{|c|}{ Model } & \multicolumn{1}{c|}{ Sum of Squares } & df & Mean Square & F & Sig. \\
\hline \multirow{1}{*}{1} & Regression & 62.009 & 7 & 8.858 & 27.656 & $.000^{\mathrm{b}}$ \\
\cline { 2 - 7 } & Residual & 63.740 & 199 & .320 & & \\
\cline { 2 - 7 } & Total & 125.749 & 206 & & & \\
\hline
\end{tabular}

a. Dependent Variable: 24. Considering all the factors mentioned above, I think I am satisfied with the supermarkets of Bangladesh

b. Predictors: (Constant), REGR factor score 7 for analysis 1, REGR factor score 6 for analysis 1, REGR factor score 5 for analysis 1 , REGR factor score 4 for analysis 1 , REGR factor score

3 for analysis 1 , REGR factor score 2 for analysis 1 , REGR factor score 1 for analysis 1

The individual factor relationships with the overall customers' experience in supermarkets show that all the customers' experience factors are significantly related. (Table 16). This indicates that each of the determinant factors is significantly related to the dependent variable i.e., the overall customers' experience in supermarkets. That means that if there is a change in the factor there will be the change in dependent variable i.e., the overall experience of the customers of supermarkets in Bangladesh.

Table 16 Coefficients

\begin{tabular}{|l|c|c|c|c|c|}
\hline \multirow{2}{*}{ Model } & \multicolumn{2}{|c|}{} & \multicolumn{2}{|c|}{$\begin{array}{c}\text { Standardized } \\
\text { Coefficients }\end{array}$} & \\
\cline { 2 - 5 } & Unstandardized Coefficients & Std Error & Beta & Sig. \\
\cline { 2 - 5 } (Constant) & B & Std & & 52.144 & .000 \\
\hline 1. Time Saving & 0.316 & 0.039 & 0.404 & 8.014 & .000 \\
\hline 2. Staff Assistance and Responsiveness & 0.296 & 0.039 & 0.379 & 7.513 & .000 \\
\hline 3. Authenticity of Goods with Clear Labeling & 0.145 & 0.039 & 0.185 & 3.671 & .000 \\
\hline 4. Return Policy & 0.174 & 0.039 & 0.222 & 4.402 & .000 \\
\hline 5. Flexible Mode of Payment & 0.085 & 0.039 & 0.109 & 2.160 & .032 \\
\hline 6. Convenient Location of Store & 0.215 & 0.039 & 0.275 & 5.454 & .000 \\
\hline 7. Competitive Pricing & 0.094 & 0.039 & 0.120 & 2.378 & .018 \\
\hline
\end{tabular}

a. Dependent Variable: 24. Considering all the factors mentioned above, I think I am satisfied with the supermarkets of Bangladesh

\section{Conclusions and Recommendations}

This study reveals that all the variables influencing the customers' experience in supermarkets of Bangladesh have high communalities indicating the variables are important in this of study. It identified that the factors that are significantly related to the customers' experience in super shops of Bangladesh. Study shows that the time saving, staff assistance and responsiveness, authenticity of goods with clear labeling, return policy, flexible mode of payment, convenient location and competitive pricing are important factors for the effectiveness of the employee training in public banks of Bangladesh. Analysis of variance shows that all the seven factors concerning the customers experience in supermarkets are significantly related to the overall customers' experience in supermarkets of Bangladesh. Model summary shows that the adjusted R square is 0.493 that indicates higher level of relationships of the factors with the overall customers' experience in supermarkets. The individual factor relationships with the overall customers' experience in supermarkets show that all the customers' experience 
factors are significantly related. This indicates that each of the determinant factors is significantly related to the dependent variable i.e., the overall customers' experience in supermarkets. That means that if there is a change in the factor there will be the change in dependent variable i.e., the overall experience of the customers of supermarkets. This study recommends that the owners of the supermarket chains of Bangladesh should focus on the saving customers' time, staff assistance and responsiveness, ensuring authenticity of goods by clearly labeling, liberal return policy, flexible mode of payment such as- card and digital payment, convenient store location and competitive pricing of goods compared to the local wet markets to increase customers' satisfaction and loyalty in supermarkets of Bangladesh. However, there is an ample scope to improve the results of this study by taking more samples in consideration in future.

\section{References}

[1] Abubakar, B., Mavondo, F., \& Clulow, V. (2001). Customer satisfaction with supermarket retail shopping. Retrieved from, 130(95.71), 8081.

[2] Azad, S. N., Hossain, M. M., \& Parveen, R. (2011). Customer perception, price and demand analysis of supermarkets in Dhaka city. Journal of Business and Technology (Dhaka), 35-51.

[3] Bloemer, J., \& De Ruyter, K. (1998). On the relationship between store image, store satisfaction and store loyalty. European Journal of marketing, 32(5/6), 499-513.

[4] Chowdhury, S. K., Salam, M., \& Hasan, M. (2014). Antecedents and Consequences of Customer Satisfaction: An Empirical Study on Retail Store in Bangladesh. Stamford Journal of Business Studies, 6 (1).

[5] Dabholkar, P. A., Thorpe, D. I., \& Rentz, J. O. (1996). A measure of service quality for retail stores: scale development and validation. Journal of the Academy of marketing Science, 24(1), 3.

[6] Fitzsimmons, J. A., Fitzsimmons, M. J., \& Fitzsimmons, J. A. (2004). Service management: Operations, strategy, and information technology.

[7] Hair, J. F., Anderson, R. E., Babin, B. J., \& Black, W. C. (2010). Multivariate data analysis: A global perspective (Vol. 7).

[8] Hossain, M., Rahman, D., \& Akter, N. (2009). Customer satisfaction to supermarkets: Bangladesh perspective. D.U. Journal of Marketing, 12.

[9] Huddleston, P., Whipple, J., Nye Mattick, R., \& Jung Lee, S. (2009). Customer satisfaction in food retailing: comparing specialty and conventional grocery stores. International Journal of Retail \& Distribution Management, 37(1), 63-80.

[10] Islam, D. (2018). An Analysis of Customers' Satisfaction of Super Markets in Bangladesh. International Journal of Research in Business, Economics and Management, 1(3), 203-220.

[11] Islam, N., Rahman, M. N., Nower, N., Rafi, M. M. A., Natasha, M. T., \& Hassan, R. (2019). Factors Affecting Customers' Experience in Mobile Banking of Bangladesh. Global Journal of Management And Business Research.

[12] Karumba, T., \& Ngigi, P. (2018). Factors That Influence Customer Choice of Supermarkets in Karatina TownNyeri County, Kenya. Scholars Journal of Economics, Business and Management (SJEBM)

[13] Malhotra, N. K. (1999). Marketing Research: An Applied Orientation. Englewood Cliffs, NJ: Prentice-Hall.

[14] Malhotra, N. K. (2007). Marketing Research - An Applied Orientation, Pearson Education, India.

[15] Mohan, R. (2013). To identify the factors impacting customer satisfaction in food retail supermarkets. International Journal of Research and Development-A Management Review (IJRDMR).

[16] Nunnally, J. U. M. (1994). C., BERSTEIN, Ira H. Psycometric theory. New York: McGraw Hill.

[17]Pilelienè, L., \& Grigaliūnaitè, V. (2013). Determination of customer satisfaction with supermarkets in Lithuania. Organizaciju vadyba: sisteminiai tyrimai, 66, 99-114.

[18] Ramya, D. (2015). Customer experience in supermarkets and hypermarkets - A comparative study. IOSR Journal of Business and Management (IOSR-JBM), 17(11), 116-123.

[19] Rana, S. S., Osman, A., \& Islam, M. A. (2014). Customer satisfaction of retail chain stores: Evidence from Bangladesh. Journal of Asian Scientific Research, 4(10), 574.

[20] Rasoly, M. (2018). A Study on Consumer Satisfaction of Supermarket in Mysore City, Mysore. International Journal of Research in Business Studies and Management, 5(5), 23-29.

[21] Shamsudeen, S. (2017). A Study on the Determinant of Customer Experience among Supermarket Shoppers in Saudi Arabia. Pyrex Journal of Business and Finance Management Research, 3(1), 23-33.

[22] Tabachnick, B. G., \& Fidell, L. S. (2001). Principal components and factor analysis. Using multivariate statistics, 4, 582-633.

[23] Thương, N. T. T. (2016). Factors Influencing Customer Satisfaction Towards Supermarkets in Thai Nguyen City, Vietnam. International journal of Economics, Commerce and Management, 4(2).

[24] Varki, S., \& Colgate, M. (2001). The role of price perceptions in an integrated model of behavioral intentions. Journal of Service Research, 3(3), 232-240.

[25] Yamane, T. (1967). Statistics, introductory Analysis of problems. 